\title{
Exclusion of close linkage between the parathyroid hormone gene and a mutant gene locus causing idiopathic hypoparathyroidism
}

\author{
J SCHMIDTKE*, K KRUSE†, B PAPE*, AND G SIPPELL \\ From *Institut für Humangenetik der Universität Göttingen, D-3400 Göttingen; †Universitätskinderklinik, \\ D-8700 Würzburg; and $\ddagger$ Universitätskinderklinik, Pädiatrische Endokrinologie, D-2300 Kiel, West Germany.
}

SUMMARY A family is presented in which the mother has transmitted primary hypoparathyroidism with early onset and serum PTH (44-68) and C terminal deficiency to her two sons. Restriction enzyme analysis of allelic variation at the PTH gene locus revealed that the disease and the PTH alleles segregate independently. It is therefore concluded that the primary molecular defect leading to this form of hypoparathyroidism is not located within the PTH gene itself.

Familial idiopathic hypoparathyroidism represents a heterogeneous group of heritable diseases. According to McKusick $^{1}$ autosomal dominant $(14620,14625)$, autosomal recessive $(24140,25634)$, and $X$ linked recessive $(30770)$ forms have been documented. The genetic lesions responsible for these conditions are as yet unknown. Here we report a family with apparent autosomal dominant idiopathic hypoparathyroidism with early onset of the disease. We have shown by DNA restriction enzyme analysis that the primary defect is not located within the parathyroid hormone gene itself.

\section{Methods}

DNA ANALYSIS

DNA was prepared from peripheral blood as described previously. ${ }^{2}$ In short, cells were lysed with Triton X-100, treated with urea and sodium dodecyl sulphate, and extracted with RNase, pronase, phenol, and chloroform. DNA samples were then digested with the restriction endonucleases BamHI, EcoRI, HindIII, MspI, PstI, and TaqI (Boehringer) following the manufacturer's recommended assay conditions and using at least a 10-fold excess of enzyme. Restricted DNA samples were run on $0.8 \%$ agarose gels in $0.14 \mathrm{~mol} / 1$ phosphate buffer, stained with ethidium bromide, denatured, neutralised, and blotted onto nitrocellulose membranes according to Southern. ${ }^{3}$ Filters were hybridised for four hours in $5 \times$ SSC, $5 \times$ Denhardt's solution, and $10 \%$ dextran sulphate at $68^{\circ} \mathrm{C}$ with approximately $5 \mathrm{ng} / \mathrm{ml}$ of

Received for publication 11 January 1986

Accepted for publication 6 February 1986 p20.36, which was radiolabelled with ${ }^{32} \mathrm{P}$ to a specific activity of about $2 \times 10^{8} \mathrm{dpm} / \mu \mathrm{g}$. p20.36 is a recombinant plasmid which contains a human prepro-PTH genomic EcoRI fragment. ${ }^{4}$ After hybridisation, filters were washed and exposed for autoradiography for 18 to 72 hours.

\section{Case report}

Two brothers, II.1 (figure), born in October 1969, and II.2, born in May 1971, and their mother I.1, born in April 1947, presented with hypocalcaemia, hyperphosphataemia, and normal alkaline phosphatase, 25-OH-vitamin D, and creatinine clearance. Subject II.1, the index case, developed what appeared to be grandmal epilepsy at the age of 8 months. Despite finding low serum calcium levels at the ages of 6 and 8 months $(7.2 \mathrm{mg} / \mathrm{dl}$ and $6.5 \mathrm{mg} / \mathrm{dl}$, respectively) the diagnosis of hypoparathyroidism was not made until 1975 when he was 5 years 4 months. The first evidence of hypoparathyroidism in the younger brother (II.2), who had no symptoms until diagnosis, and the mother, who had 'epilepsy' from the age of 2 years, was revealed at the age of 5 years and 28 years, respectively.

The father of I.1 died from a myocardial infarction and had no history of fits. His brother's granddaughter suffers from epilepsy. Determinations of serum calcium and phosphorus in this child and the mother, sister, brothers, and husband of I.1 showed normal levels.

Serum iPTH determined with different antisera was low in relation to marked hypocalcaemia. Measurements of iPTH with assay systems detecting $\mathrm{N}$ terminal and 28-48 hormone fragments revealed 

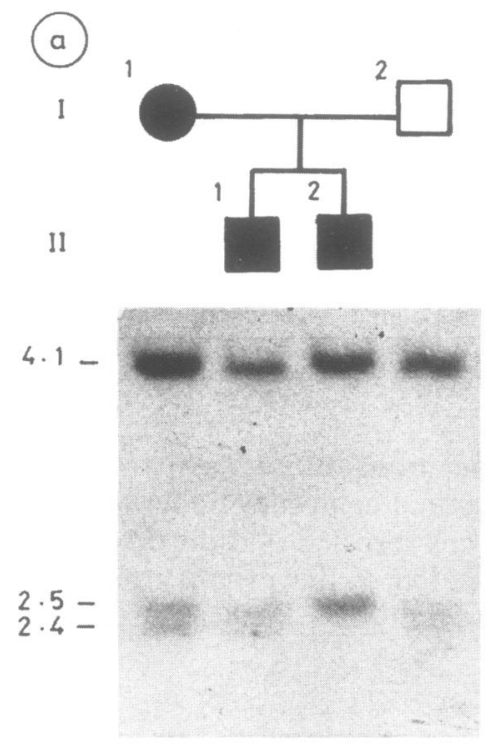

Taq 1
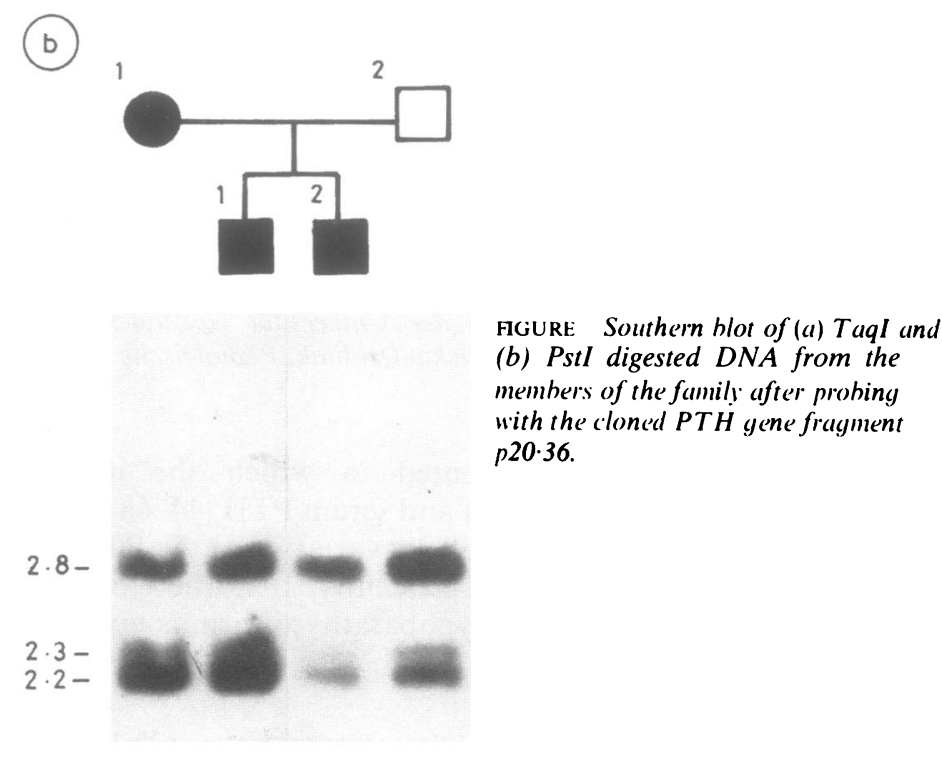

Pst I 'normal' instead of increased values in relation to hypocalcaemia, whereas low or undetectable levels were measured using 44-68 and $C$ terminal assays. Intravenous parathyroid extract immediately increased urinary cAMP excretion and reduced $\mathrm{TmPO}_{4} / \mathrm{GFR}$, and prolonged intramuscular parathyroid extract led to a progressive increase of total serum calcium in both brothers.

After the diagnosis of idiopathic hypoparathyroidism was established, vitamin $D_{3}$, and later dihydrotachysterol (AT10) treatment was started in the two brothers and their mother. During treatment with 1 to $2 \mathrm{mg}$ AT10 per day, serum calcium levels returned to normal in them all, but there was a tendency to hypercalciuria and hypomagnesaemia $(1.4$ to $1.5 \mathrm{mg} / \mathrm{dl}$, normal 1.7 to $2.1 \mathrm{mg} / \mathrm{dl})$ despite normocalcaemia. Oral or intravenous magnesium treatment had no effect on serum iPTH levels and urinary cAMP excretion.

\section{Results}

Restriction enzyme analysis of DNA from the two affected brothers and their affected mother with BamHI, EcoRI, HindIII, MspI, PstI, and TaqI revealed a normal banding pattern after probing with the cloned PTH gene fragment p20.36, using the unaffected father and other unrelated healthy persons as controls (data not shown). It was, therefore, concluded that no major gene alterations such as gross deletions, insertions, or rearrangements had occurred in the PTH gene regions of our patients.

The cloned PTH gene fragment p20.36 revealed two high frequency restriction fragment length polymorphisms using TaqI and PstI. ${ }^{5}$ Due to a polymorphic $T a q I$ site within the second intron of the prepro-PTH locus, TaqI restriction fragments of either 2.4 or $2.5 \mathrm{~kb}$ are generated in addition to a $4.1 \mathrm{~kb}$ invariant fragment. A polymorphic PstI site $1.7 \mathrm{~kb} 3^{\prime}$ to the coding region produces Pst fragments of either 2.2 or $2.8 \mathrm{~kb}$ in addition to another $2 \cdot 2 \mathrm{~kb}$ invariant fragment, and $2 \cdot 8 / 2 \cdot 8 \mathrm{~kb}$ homozygotes can be easily distinguished from $2 \cdot 8 / 2 \cdot 2 \mathrm{~kb}$ heterozygotes on the basis of relative band intensity. ${ }^{56}$ Furthermore, an invariant, more faintly cross hybridising $2.3 \mathrm{~kb}$ PstI sequence of unknown location and function becomes apparent. ${ }^{5}$

These restriction fragment length polymorphisms were used in order to determine whether the affected mother passed identical or different PTH alleles to her two affected sons. As can be seen in the figure (a), the mother (I.1), the father (I.2), and the older son (II.1) are heterozygous for the 2.5 and $2.4 \mathrm{~kb} \mathrm{TaqI}$ alleles, while the younger son (II.2) is homozygous for the $2.5 \mathrm{~kb}$ allele. On the basis of these patterns it is not possible to establish whether the two sons inherited identical or different maternal PTH alleles. The PstI polymorphism in this family can be seen in the figure (b). The mother and son II.1 are heterozygous for the 2.8 and $2.2 \mathrm{~kb}$ PstI alleles, while the 
father and son II. 2 are homozygous for the $2.8 \mathrm{~kb}$ Pst $\mathrm{I}$ allele. This interpretation was confirmed by densitometry of the autoradiograph. Thus, the mother has passed the $2.8 \mathrm{~kb}$ PTH allele to son II.2 and the $2.2 \mathrm{~kb}$ PTH allele to son II.1. The disease, therefore, segregates independently of the PTH allelic variants. Paternity was confirmed by HLA typing (data not shown).

\section{Discussion}

We have shown by clinical, immunological, and restriction endonuclease analysis that in a family with idiopathic hypoparathyroidism with low or undetectable serum levels of PTH using 44-68 and C terminal assays, in which the disease seems to be transmitted by the affected mother to both of her sons, the genetic defect is not linked to the PTH gene itself, and that the primary molecular defect must be located elsewhere (for example, defective processing, synthesis, or secretion of PTH). These conclusions are based on the assumption that the pattern of inheritance is in fact autosomal dominant. Several alternatives should, however, be considered. Theoretically, the mother could be homozygous and the father heterozygous for a recessive allele with a $50 \%$ chance of each offspring being affected. However, given the rarity of these disorders in the population, the probability of the father being heterozygous can be considered to be very low. There is no evidence for consanguinity in the parents. Secondly, a crossover event may have occurred during maternal meiosis between the PstI site and the site of a putative mutation in the PTH gene giving rise to the disease. Again, this must be very unlikely. Assuming that $1000 \mathrm{~kb}$ of the human genome corresponds to $1 \mathrm{cM}$, a recombination event would occur with a probability of only $0.002 \%$. Thirdly, the pedigree could also formally be interpreted as showing $X$ linked dominant inheritance; such a mode of inheritance would also exclude linkage of the disease locus with the PTH gene, because the latter is located on chromosome $11 .^{4}$

While this investigation does not contribute directly to the identification of a genetic defect, it demonstrates the usefulness of recombinant DNA methods in unravelling a heterogeneous group of disorders. It is hoped that this communication will prompt similar analyses of other families with a view to determining the molecular basis of this rare condition.

JS was supported by grants from DFG and BMFT. We thank Dr E Westphal, Kiel, for HLA typing, and Mrs M Pelz for secretarial help.

\footnotetext{
References

1 McKusick VA. Mendelian inheritance in man. Baltimore, London: Johns Hopkins University Press, 1983.

2 Cooper DN, Smith BA. Cooke HJ, Niemann S, Schmidtke J. An estimate of unique DNA sequence heterozygosity in the human genome. Hum Genet 1985:69:201-5.

3 Southern EM. Detection of specific sequences among DNA fragments separated by gel electrophoresis. J Mol Biol 1975;98: 503-17.

4 Mayer H, Breyel E, Bostock C, Schmidtke J. Assignment of the human parathyroid hormone gene to chromosome 11. Hum Genet 1983;64:283-5.

5 Schmidtke J, Pape B, Krengel U, et al. Restriction fragment length polymorphisms at the human parathyroid hormone gene locus. Hum Genet 1984:67:428-31.

6 Antonarakis SE. Phillips JA. Mallone RL, et al. $\beta$-globin locus is linked to the parathyroid hormone (PTH) locus and lies between the insulin and PTH loci in man. Proc Natl Acad Sci USA 1983;80:6615-9.
}

Correspondence and requests for reprints to $\mathrm{Dr} J$ Schmidtke, Institut für Humangenetik der Universität, Gosslerstrasse 12d, D-3400 Göttingen, West Germany. 